\title{
Penatalaksanaan disgnati kelas II skeletal dengan bilateral sagital split osteotomy
}

\author{
*Muhammad Ruslin, ${ }^{* *}$ Ida Ayu Astuti, ${ }^{* * *}$ D. Bram Tuinzing \\ "Bagian Bedah Mulut dan Maksilofasial FKG-Universitas Hasanuddin Makassar, Indonesia \\ *** Bagian Bedah Mulut dan Maksilofasial FKG-UNPAD/RSUP dr. Hasan Sadikin Bandung, Indonesia \\ **** Department of Oral and Maxillofacial Surgery/Oral Pathology, VU University Medical Center/ \\ Academic Center for Dentistry Amsterdam (ACTA), Amsterdam, The Netherlands
}

\begin{abstract}
This case reported a female patient aged 30 years was treated with orthognathy surgery in Hasan Sadikin Hospital, Bandung. Based on clinical and radiological examinations, model study and photography, diagnosis of skeletal dysgnathy class II was established. The orthodontic treatment is a preparation before surgical operation to achieve stability in optimal dental interdigitation. In operation, BSSO, chinplasty, and $V$-Y plastic upper lip as well as intermaxillary fixation (IMF) ligation was carried out at the dentofacial position class I. At day-16, radiography was carried out to evaluate the surgical outcome and the bone position. At day-21, the opening of jaws was $1.5 \mathrm{~cm}$; and at day-42, the patient was reconsulted to orthodontist, and to physical medicine and rehabilitation In month-3, occlusion, facial profile and harmony, and jaw functions showed the satisfying outcome, though for the interdigitation stabilization, the rubber elastics was still installed.
\end{abstract}

Keywords: dysgnaty, class II skeletal, orthognathic surgery

\begin{abstract}
ABSTRAK
Dilaporkan seorang wanita berusia 30 tahun dengan retardasi mental ringan disertai disfagia dirawat dengan bedah ortognati di RS Hasan Sadikin Bandung. Berdasarkan pemeriksaan klinis, radiologi, studi model dan fotografi, ditegakkan diagnosis disgnati kelas II skeletal. Perawatan ortodontik dilakukan sebagai persiapan pembedahan untuk mencapai stabilitas interdigitasi dental yang optimal. Pada pelaksanaan operasi dilakukan BSSO, chinplasty, dan $V-Y$ plastic upper lip serta fiksasi intermaksila pada posisi dentofasial kelas I. Pada hari ke-16, hasil operasi serta posisi tulang dievaluasi dengan radiografi. Pada hari ke-21, bukaan rahang $1,5 \mathrm{~cm}$. Pada hari ke-42, pasien dikonsul kembali ke ahli ortodonti untuk melanjutkan perawatan, dan dokter spesialis rehabilitasi medik untuk terapi disfagia, drolling, involunter otot wajah. Pada bulan ke-3 pascaoperasi, oklusi, profil dan harmoni wajah, dan fungsi rahang memuaskan, meskipun untuk stabilisasi interdigitasi masih dipasang rubber elastic.
\end{abstract}

Kata kunci:disgnati, klas II skeletal, bedah ortognatik

Koresponden: Muhammad Ruslin, Bagian Bedah Mulut dan Maksilofasial FKGUniversitas Hasanuddin Makassar, Jl. Kandea No. 5 Makassar 90135, Telp. (0411) 318715, 0811236191, E-mail: m.ruslin@unhas.ac.id

\section{PENDAHULUAN}

Bedah ortognatik merupakan suatu perawatan kombinasi antara perawatan bedah dan perawatan ortodontik. Seringkali untuk keadaan dengan abnormalitas dental dan rahang serta deformitas wajah, tidak dapat dikoreksi hanya dengan perawatan ortodontik saja tetapi membutuhkan koreksi dengan pembedahan. Perawatan ini bertujuan untuk memperbaiki keadaan disgnati berupa maloklusi dental dan displasia fasial yang disebabkan kelainan yang parah dalam ukuran, bentuk dan hubungan antar kedua rahang maupun dengan basis kranial. Secara sederhana bedah ortognatik didefinisikan sebagai pengaturan 
rahang yang bertujuan untuk memperbaiki hubungan antar rahang dan jaringan sekitarnya dalam suatu kompleks kraniofasial. Keberhasilan dari perawatan sangat memerlukan pemahaman mengenai oklusi gigi, pertumbuhan wajah, gnatologi fungsional dan estetik wajah. ${ }^{1-2}$

Koreksi mandibula dapat dilakukan dengan teknik vertical ramus osteotomy (VRO) atau teknik bilateral sagittal split osteotomy (BSSO). Pada VRO, jarang merusak bundel neurovaskular dibandingkan dengan BSSO, tetapi VRO hanya dapat memundurkan mandibula kurang dari 10 $\mathrm{mm}$ dan harus menggunakan fiksasi intermaksila. Sedangkan BSSO dapat memundurkan dan memajukan mandibula lebih dari $10 \mathrm{~mm}$; sedangkan kekurangannya adalah memerlukan tambahan biaya untuk pemasangan plate. ${ }^{1,2}$

Pada makalah ini, dibahas suatu kasus disgnati klas II pada seorang wanita berumur 30 tahun dengan retardasi mental ringan disertai disfagia yang dirawat dengan bedah ortognatik yang meliputi bilateral sagittal split osteotomy, chinplasty, dan V-Y plastic upper lip.

\section{LAPORAN KASUS}

Pada tanggal 24 November 2008, seorang wanita datang ke bagian Bedah Mulut dan Maksilofasial RSHS dengan keluhan utama sulit untuk mengunyah, rahang bawah mundur ke belakang, otot wajah dan rahang pegal ketika makan, dan bila membuka mulut lebar terdengar bunyi pada sendi rahang. Dari anamnesis diperoleh informasi saat berusia 5 tahun terdapat riwayat trauma kepala. Sejak kejadian tersebut penderita susah makan makanan padat dan sulit menelan terutama makanan cair sehingga sering tersedak dan dagu mundur ke belakang sejak kecil. Pada saat pasien menguap terasa pegal dan sakit, serta terdengar bunyi klik pada sendi rahang kiri dan kanan, serta telinga berdenging.

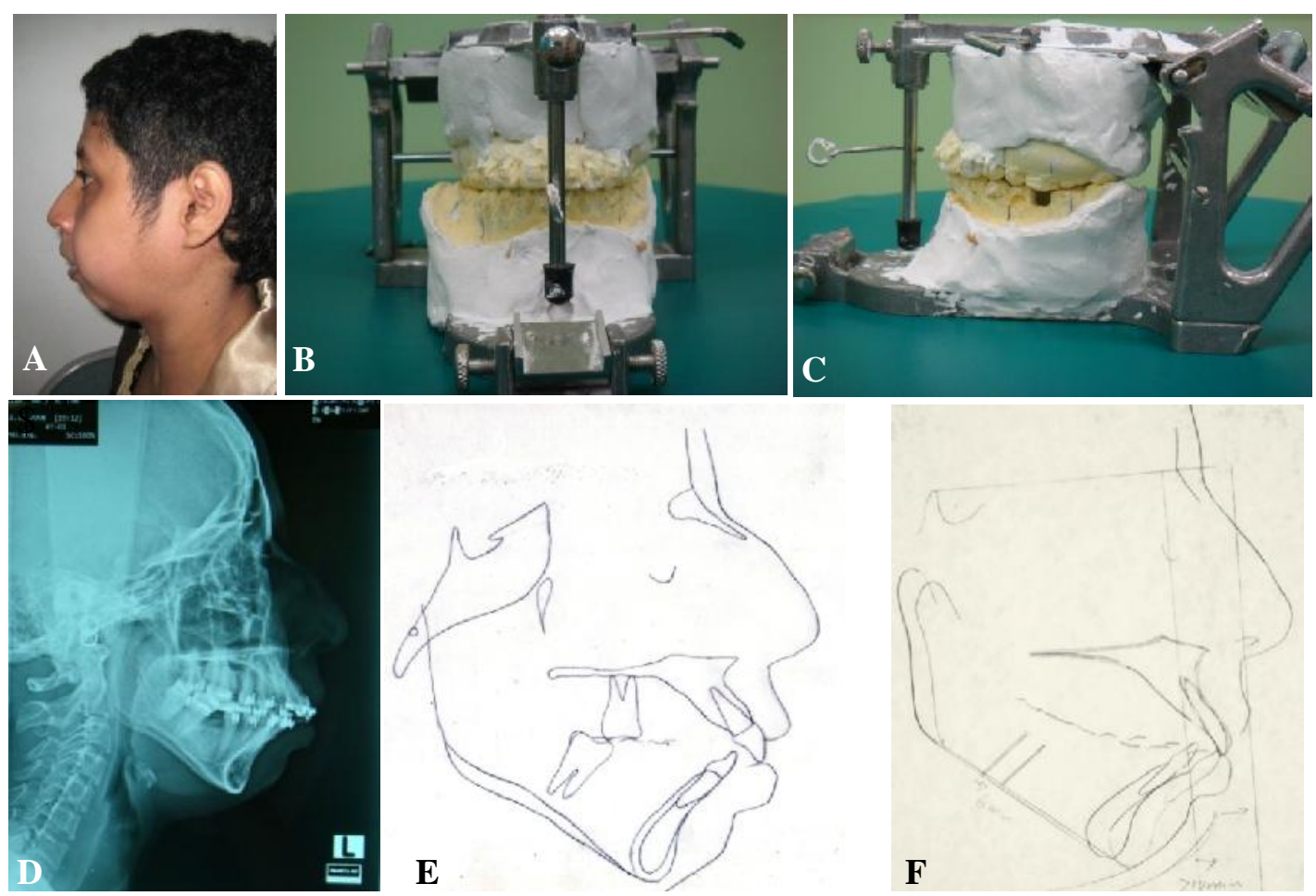

Gambar 1. A. Foto lateral kiri, B. Model studi yang menggambarkan oklusi pasien pasca operasi lateral kiri, C. Model studi tampak depan. D. Foto sefalometri, E. Hasil tracing foto sefalometri, F. Hasil tracing foto sefalometri yang menggambarkan oklusi pasca operasi. 
Kesadaran pasien compos mentis, tensi 110/80 mm Hg, napas 16x/menit, nadi 80x/menit, suhu afebris, ekspresi tenang. Pada ekstra oral tampak rahang bawah mundur ke belakang, bibir atas protrusi, bibir bawah retrusi, drooling, lip seal tidak adekuat, paresis N.VII kanan perifer, monoparesis ekstremitas kiri atas (gambar 1A). Pada intra oral, gigi 16, 36, 46 dicabut pasca perawatan ortodontik, dan gerak lidah terbatas.

Inklinasi gigi disgnati kelas II pasca perawatan ortodontik (gambar 1B dan 1C), dan analisis radiografis (Gambar 1D, 1E, dan 1F) diperoleh dataran oklusal maksila steep dan mandibula flat, dagu pendek dan retrusi, overjet, maka pasien didiagnosis disgnati kelas II skletal dengan retardasi mental ringan disertai disfagia. Rencana perawatan bedah ortognatik, meliputi BSSO, genioplasti, dan $V$-Y plastic upper lip.

\section{PENATALAKSANAAN KASUS}

Tiga hari kemudian setelah alat, bahan, pasien, operator dan asisten siap, dilakukan intubasi dengan NTT dan dilakukan operasi.

\section{Tahap I Chinplasty}

Dilakukan pembuatan pola insisi dengan methylen blue pada vestibulum anterior mandibula (gambar 2A), injeksi hemostatik lokal dengan adrenalin 1:200.000 di sekitar pola garis insisi (gambar 2B). Insisi dengan blade no. 15 dilakukan sesuai pola, jaringan lunak dipisahkan dari tulang dengan raspatorium sampai tulang tampak dengan jelas (gambar 2C). Pada tulang dagu dibuat pola dengan menggunakan bur tulang (gambar 2D) yang dilanjutkan dengan pemotongan tulang sesuai pola dengan menggunakan reciprocating saw (gambar 2E). Setelah tulang anterior dagu mandibula dipotong maka dicoba menggerakkan tulang dagu tersebut ke anterior dan lateral dengan klem tulang (gambar 2F). Setelah cukup bebas lalu dipasang mini plate masing masing 3 hole dan 2 screw (gambar 2G). Kemudian insisi dijahit kembali lapis demi lapis (gambar 2H).

\section{Tahap II Bilateral sagittal split osteotomy}

Dilakukan injeksi hemostatik lokal dengan adrenalin 1:200.000 di sekitar garis insisi, lalu
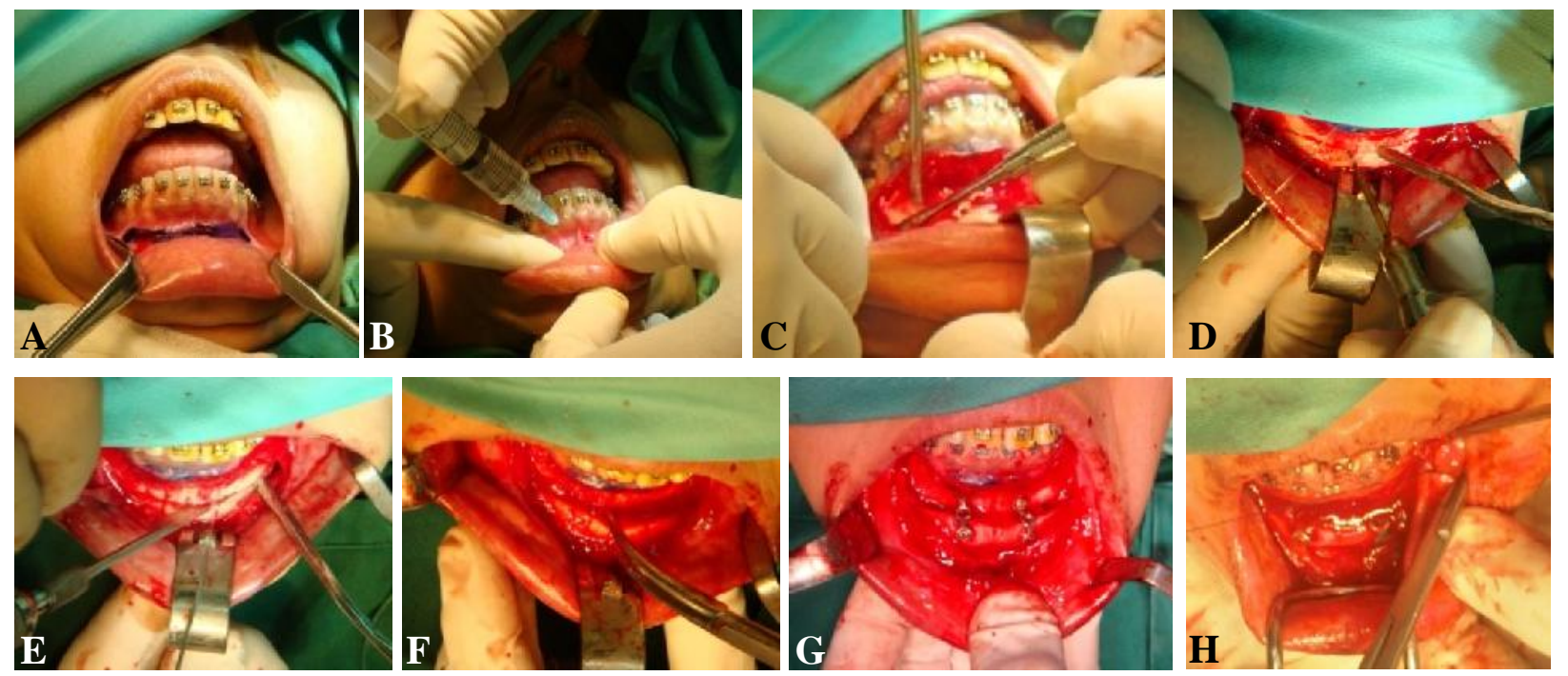

Gambar 2. Prosedur chinplasty A. Pembuatan pola insisi, B. Injeksi hemostatik lokal, C. Pemisahan jaringan lunak dengan tulang, D. Pembuatan pola pada tulang dagu, E. Pemotongan tulang menggunakan reciprocating saw, F. Tulang dagu digerakkan ke anterior dan ke lateral dengan klem tulang, G. Pemasangan mini plate, H. Penjahitan lapis demi lapis. 

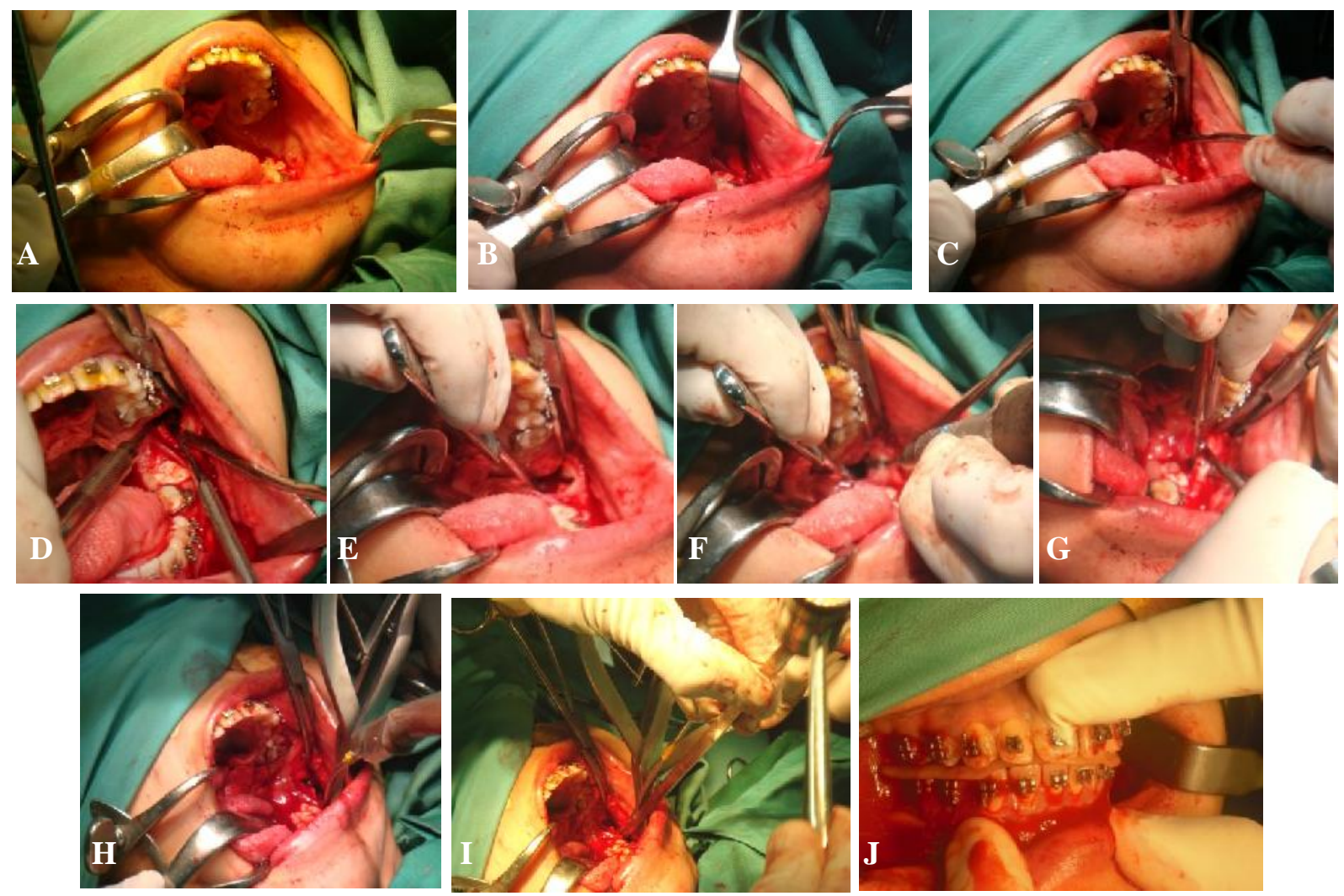

Gambar 3. Prosedur BSSO: A. Pemasangan mouth gag, cheek retractor dan spatula lidah, B. Langenbeck ramus retractor $\mathrm{V}$ pada batas depan ramus, C. Penggunaan forcep cryle toothed, D. Mengidentifikasi foramen n. mandibularis dengan instrumen Ash nomer 6, E. Saat pengasahan horisontal raspa Williger's diletakkan pada fovea dekat foramen sudut $45^{\circ}$ untuk melindungi bundel neurovaskuler, F. Pengasahan tulang pada bagian lateral korpus mandibula, G. Lokasi pengasahan tulang horisontal dan vertikal dihubungkan dengan reciprocating saw, $\mathbf{H}$ dan $\mathbf{I}$. Pemisahan tulang dengan raspa Williger's dan separator tulang, J. Maksila dan mandibula dioklusikan menggunakan wafer.

pemasangan mouth gag pada sisi kontra lateral, cheek retractor dan spatula lidah untuk memperoleh lapangan operasi yang cukup (gambar 3A). Dengan scalpel handle yang panjang insisi dibuat pada jaringan lunak setinggi trigonum retromolar dimulai dari medial dengan insisi sedalam mukosa kemudian lebih dalam sampai periosteum pada batas anterior ramus ascenden sampai molar pertama dan diperluas ke lateral sampai molar kedua. Jaringan lunak dipisahkan dengan tulang menggunakan raspa Williger's untuk mendapatkan batas bawah tulang mandibula diikuti dengan penempatan Obwegeser's retractor yang besar dan cheek retractor dapat dilepas kemudian Langenbeck ramus retractor berbentuk $\mathrm{V}$ ditempatkan pada batas depan ramus sampai dasar prosesus koronoid untuk mendapatkan daerah yang lebih luas (gambar 3B). Forcep Cryle toothed digunakan setelah rectractor dilepas (gambar 3C).

Instrumen Ash nomor 6 digunakan untuk menentukan lokasi sigmoid notch yang ditelusuri dari lateral dan ke arah medial untuk mengidentifikasi foramen $n$. mandibularis (gambar 3D). Pada saat dilakukan pengasahan secara horizontal raspa Williger's diletakkan pada fovea dekat foramen dengan sudut $45^{\circ}$ untuk melindungi bundel neurovaskuler (gambar 3E).

Pengasahan tulang juga dilakukan pada bagian lateral korpus mandibula sampai ke dalam 


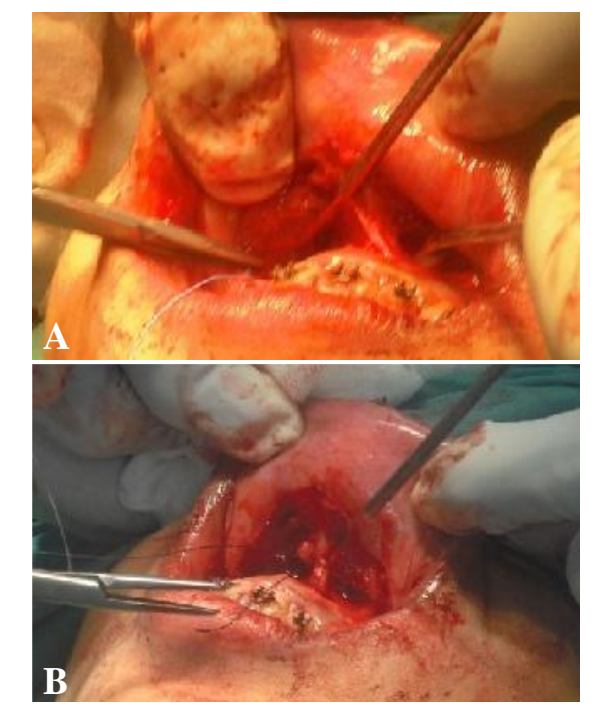

Gambar 4.Prosedur $V$ - $Y$ plastic upper lip. A. Pemisahan jaringan insisi $\mathrm{V}-\mathrm{Y}$ dengan rasparatorium, B. Daerah insisi dijahit untuk menurunkan perlekatan jaringan lunak.

korteks tulang dengan menggunakan bur Lindemann ukuran medium (gambar 3F). Lokasi pengasahan tulang tulang horisontal dan vertikal dihubungkan dengan reciprocating saw (gambar 3G) sedalam $7 \mathrm{~mm}$ ke arah tulang kanselous untuk mencegah kemungkinan rusaknya bundel neurovaskular. Pemisahan tulang dilanjutkan dengan raspa Williger's dan bone separator yang diletakkan di bagian tengah dan 1/3 anterior pada bagian tulang vertikal dengan kedalaman 5-10 mm (gambar 3.H,I). Hal yang sama dilakukan pada sisi sebelah, kemudian semua instrumen dilepas, bagian distal dan proksimal dimobilisasi dengan satu tangan untuk mengatur letak anteroposterior. Selanjutnya maksila dan mandibula dioklusikan menggunakan wafer mengikuti pola oklusi pada model (gambar 3.J). Fiksasi intermaksila dilakukan dengan wire sisi posterior kiri dan kanan pada braket ortodontik, kemudian manipulasi kedudukan kondilus pada posisi sentrik di atas dan bagian tengah dari fosa glenoidalis, dan dilakukan fiksasi dengan plat dan screw pada bagian kiri dan kanan, dilanjutkan spooling larutan $\mathrm{NaCl} \quad 0,9 \%$ lalu dilakukan penjahitan lapis demi lapis.

\section{Tahap III V-Y Plastic Upper Lip}

Untuk menambah ketinggian bibir atas, dilakukan teknik $V$-Y plastic, yaitu bibir ditarik dengan retraktor Lagenbeck kemudian diinsisi sampai ke periosteum dari premolar pertama melalui bagian bawah spina nasalis anterior ke sisi sebelahnya (gambar 4A). Perlekatan jaringan lunak dan periosteum dideseksi dengan raspa Williger's, kemudian dilakukan penjahitan dengan vicryl 4/0 (gambar 4B).

Hari 1 pasca operasi: pembengkakan $(+)$, sakit $(+)$, perdarahan (-), dilakukan transfusi PRC 2 labu karena $\mathrm{Hb}$ pasca operasi 8,2 g/dl dan hasil $\mathrm{Hb}$ pasca transfusi $10.9 \mathrm{~g} / \mathrm{dl}$, infus ringer laktat: Dextrose $5 \%=2: 1$, diet cair ensure 7 gelas/hari, IMF rubber elastik terpasang, kateter terpasang, Ceftriaxone inj. 2 x 1 gr, Kaltrofen 2 x 1 amp, Kalmetason inj 3 x $8 \mathrm{mg}$. (selama dua hari), Rantin inj 2 x 1 amp, pada sudut mulut diaplikasikan Kenalog orabase dan spooling intra oral dengan $\mathrm{NaCl} 0,9 \% 2$ x sehari.

Hari ke 2 pasca operasi: pembengkakan (+), sakit (-), perdarahan (-), infus ringer laktat: Dextrose 5\% = 2 : 1, IMF rubber elastik terpasang, diet cair ensure 7 gelas/hari, kateter dilepas, Ceftriaxone inj. 2 x 1 gr, Kaltrofen 2 x 1 amp, Kalmetason inj $3 \times 8 \mathrm{mg}$. (selama dua hari), Rantin inj 2 x 1 amp, pada sudut mulut diaplikasikan Kenalog orabase dan spooling intra oral dengan $\mathrm{NaCl}$ 0,9\% 2 x sehari.

Hari ke 3 pasca operasi: pembengkakan (+), sakit (-), infus ringer laktat: Dextrose 5\% $=2: 1$, diet cair ensure 7 gelas/hari, IMF rubber elastik terpasang, Ceftriaxone inj. 2 x 1 gr, Kaltrofen 2 x 1 amp, Rantin inj $2 \times 1$ amp, pada sudut mulut 
diaplikasikan Kenalog orabase dan spooling intra oral dengan $\mathrm{NaCl} 0,9 \% 2$ x sehari.

Hari ke 4 pasca operasi: pembengkakan (+), sesak (-), infus dilepas, IMF rubber elastik terpasang, pasien rawat jalan dan dikontrol di poli Bedah Mulut. Obat diganti per oral Cefat kaplet 3 x $500 \mathrm{mg}$, Kaltrofen tab 3 x $200 \mathrm{mg}$, Ranitidin tab 2 x $150 \mathrm{mg}$. Pada sudut mulut diaplikasikan Kenalog orabase dan spooling intra oral dengan $\mathrm{NaCl} 0,9 \%$, kasa verban pada dagu diganti dan dipertahankan sampai hari ke 10.

Pada hari ke 16 pasca operasi: dilakukan foto kontrol panoramik (gambar 5A,B) dan sefalometri (gambar 5 C,D) untuk mengevaluasi hasil operasi dan posisi tulang yang dalam batas normal.

Kontrol 3 minggu pasca operasi. Drolling (+), stabilitas oklusi (-), sehingga pemasangan rubber elastic diteruskan dan dipasang rubber elastic dan interdental wiring (gambar $5 \mathrm{E}, \mathrm{F}$ ).

Kontrol 42 hari pasca operasi. Drolling (+), involunter otot wajah (+), stabilisasi oklusi (-), sehingga pemasangan interdental wiring dan rubber elastic tetap diteruskan. Dengan kondisi ini pasien dikonsulkan ke dokter spesialis rehabilitasi medik untuk terapi prilaku (dysphagia, drolling, involunter otot wajah) (gambar 6A,B,C,D).

\section{PEMBAHASAN}

Tindakan bedah ortognati ini diindikasikan pada kasus dengan konstruksi wajah yang berkembang secara tidak normal. Ketidakserasian proporsi wajah ini memerlukan koreksi terhadap mandibula maupun maksila. Berbagai teknik digunakan untuk koreksi proporsi wajah.
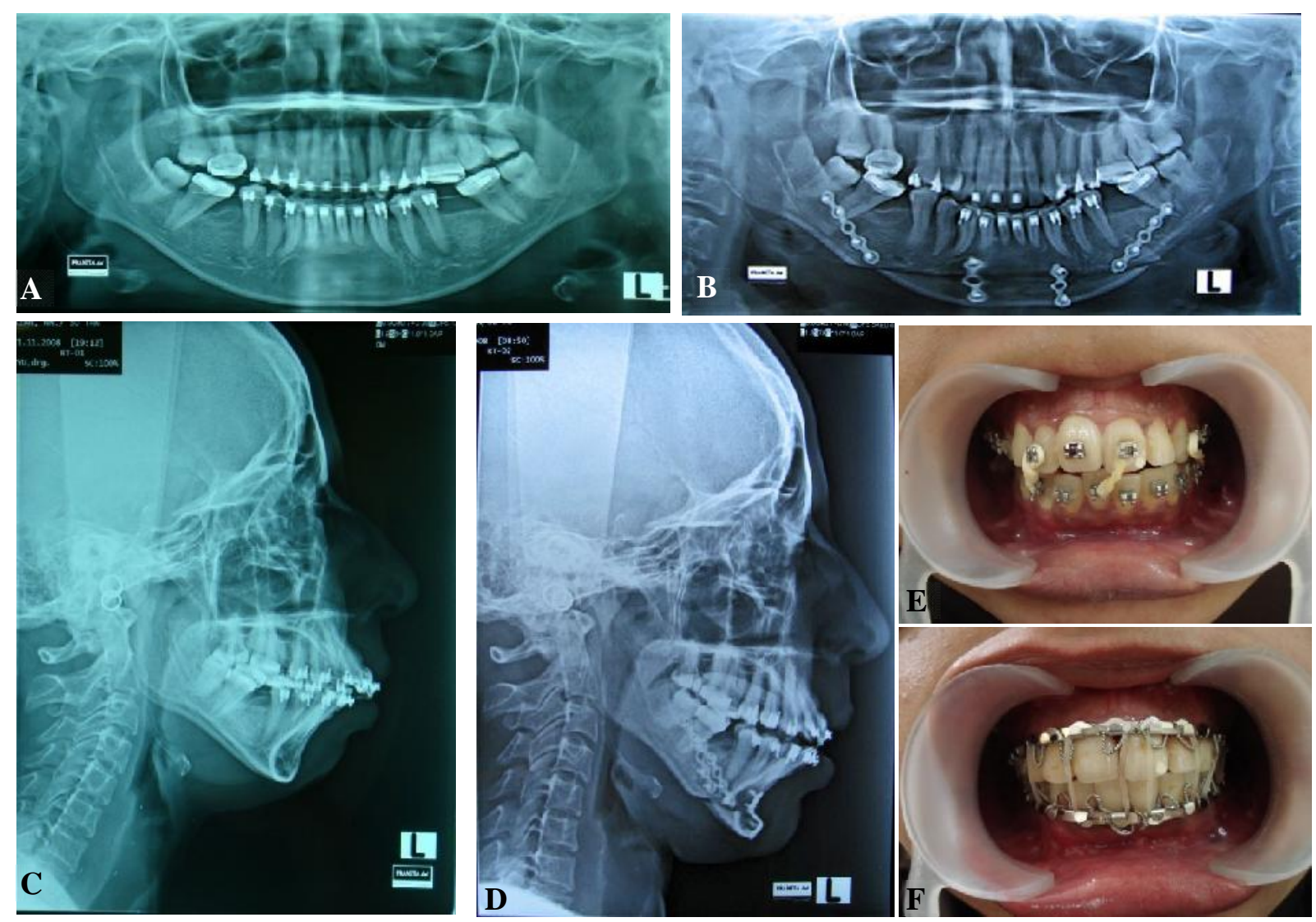

Gambar 5. Foto kontrol radiografi. Foto Panoramik A. pre operasi dan B. pasca operasi; foto sefalometri C. pre operasi dan D.pasca operasi; foto oklusi E. sebelum dan F.sesudah pemasanagan interdental wiring dengan rubber elastic. 

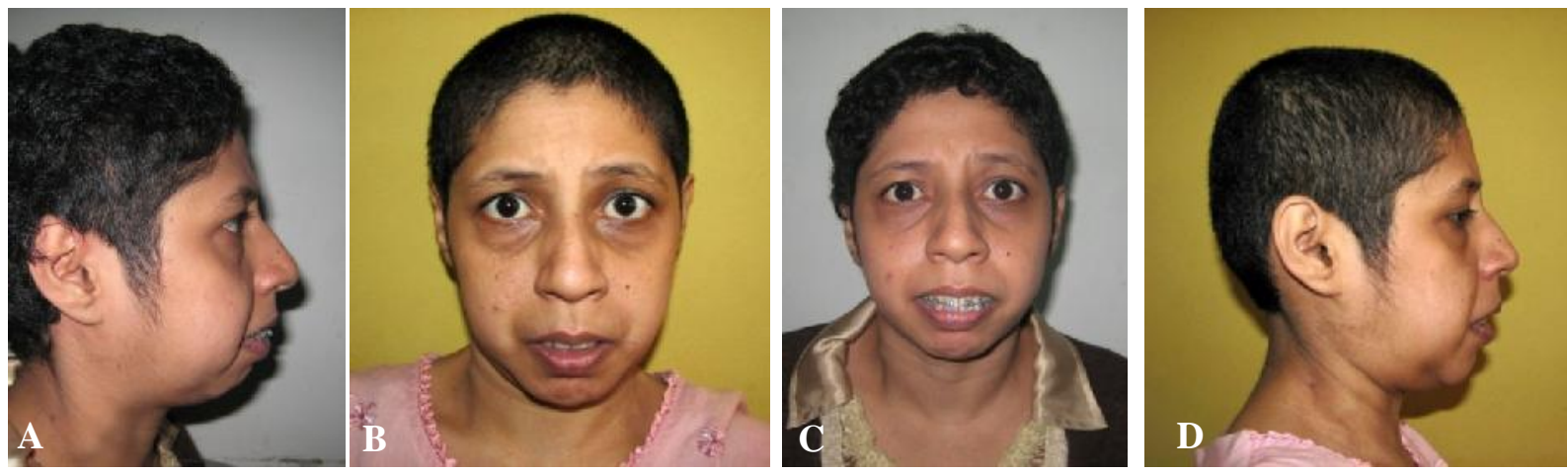

Gambar 7. Foto close up penderita, A, B. pre operasi; C, D. pasca operasi.

Osteotomi mandibula merupakan salah satu bagian tindakan koreksi proporsi wajah. Osteotomi mandibula dapat dilakukan pada bagian ramus, body, dentoalveolar dan dagu sesuai diagnosis dan kelainan dentofasial. Pemotongan pada bagian ramus mandibula untuk mendapatkan relasi yang diinginkan merupakan teknik yang populer saat ini. Teknik ini biasanya dilakukan pada dua sisi namun pada kelainan rahang sebelah tetap dapat digunakan sesuai indikasinya. ${ }^{2-4}$

Dua teknik yang saat ini sering digunakan untuk koreksi disgnati adalah VRO dan BSSO. Secara umum kedua teknik tersebut bertujuan untuk memperbaiki sudut mandibula yang bermasalah terhadap tulang kranial. Pada deformitas yang parah maka osteotomi ramus dapat dikombinasikan dengan osteotomi pada dagu atau alveolar. Keuntungan teknik VRO bila dibandingkan dengan teknik BSSO, antara lain trauma terhadap bundel saraf yang minimal, waktu operasi relatif lebih singkat, resiko perdarahan lebih minimal, dan tidak memerlukan plat dan skrup sehingga biaya lebih minimal.Sedangkan keuntungan teknik BSSO adalah dapat setback maupun advancement lebih dari $10 \mathrm{~mm}$ dan tidak memerlukan fiksasi intermaksila. ${ }^{1-5}$

\section{Gambaran umum BSSO}

Teknik BSSO, pertama kali diperkenalkan oleh Obwegeser dan Trauner pada tahun 1957, dan menjadi populer digunakan untuk mengoreksi kelainan prognati hingga saat ini. Teknik ini dilakukan dengan pendekatan intraoral dan dapat dilakukan setback maupun advancement lebih dari $10 \mathrm{~mm}$, namun kekurangannya dibandingkan VRO memerlukan plat. $^{2-4}$

Bilateral sagittal split osteotomy yang bertujuan untuk memajukan rahang bawah maka mandibular plane sangat penting. Counterclockwise atau anterior rotational movement posisi mandibula kurang stabil sehingga sering mengakibatkan relaps, begitu juga jika memajukan mandibula lebih dari $10 \mathrm{~mm}$. Tetapi jika mandibular plane sejajar dengan posisi awal atau pergerakan clockwise kearah rotasi posterior dapat memberikan posisi yang stabil.

Kekurangan besar teknik ini adalah dapat merusak bundel neurovaskular mandibula yang menginervasi bibir bawah dan dagu. Hal ini perlu disampaikan ke pasien jika beberapa waktu ditemukan rasa baal pada bibir bawah dan dagu selama beberapa minggu atau bulan setelah operasi. Keuntungan teknik ini dapat digunakan plat dan skrup sehingga memungkinkan tidak menggunakan fiksasi intermaksila, dan keluhan sendi rahang jarang terjadi.

Gigi molar ketiga yang impaksi disarankan untuk dicabut minimal 6 bulan sebelumnya untuk mendapatkan penyembuhan tulang yang maksimal sebelum tindakan bedah ortognatik. Hal ini 
dilakukan untuk memudahkan sagittal split osteotomy dan fiksasi skrup. ${ }^{2}$

\section{Aspek teknik BSSO}

Untuk memperoleh lapangan operasi yang cukup dilakukan pemasangan cheek retractor dan spatula lidah serta mouth gag pada sisi kontra lateral. Pada teknik ini insisi dibuat pada jaringan lunak setinggi trigomum retromolar dimulai dari medial dengan insisi sedalam mukosa kemudian insisi lebih dalam sampai periosteum pada batas anterior ramus ascenden sampai molar pertama dan diperluas ke lateral sampai molar kedua. Jaringan lunak dipisahkan dengan tulang menggunakan raspa Williger's untuk mendapatkan batas bawah tulang mandibula diikuti dengan penempatan Obwegeser's retractor yang besar dan cheek retractor dapat dilepas. Selanjutnya Langenbeck ramus retractor berbentuk V ditempatkan pada batas depan ramus untuk mendapatkan daerah yang lebih luas hingga dasar prosesus koronoid dan forcep cryle toothed digunakan setelah retraktor dilepas.

Instrumen Ash nomer 6 digunakan untuk menentukan lokasi sigmoid notch yang ditelusuri dari lateral dan medial untuk mengidentifikasi foramen n. mandibularis. Pada saat dilakukan pengasahan secara horisontal raspa Williger's diletakkan pada fovea dekat foramen dengan sudut $45^{\circ}$ untuk melindungi bundel neurovaskuler.

Pengasahan tulang juga dilakukan pada bagian lateral korpus mandibula sampai kedalam kortikal tulang dengan menggunakan bur Lindemann ukuran medium. Lokasi pengasahan tulang horisontal dan vertikal dihubungkan dengan reciprocating saw sedalam $7 \mathrm{~mm}$ ke arah tulang kanselus untuk mencegah kerusakan bundel neurovaskular. Pemisahan tulang dilanjutkan dengan raspa Williger's dan separator tulang yang diletakkan di bagian tengah dan 1/3 anterior pada insisi tulang vertikal dengan kedalam 5-10 mm. Hal yang sama dilakukan pada sisi yang berlawanan, kemudian semua instrumen dilepas dan bagian distal dan proksimal dimobilisasi menggunakan satu tangan untuk memanipulasi posisi anteroposterior yang diinginkan. Kemudian maksila dan mandibula dioklusikan mengikuti pola oklusi pada model dan manipulasi kedudukan kondilus pada posisi sentrik di atas dan bagian tengah dari fosa glenoidalis. Fiksasi intermaksila sementara dengan kawat $0,5 \mathrm{~mm}$ sisi posterior kiri dan kanan pada braket ortodontik, kemudian dilakukan fiksasi dengan plat dan skrup pada bagian kiri dan kanan. Kawat dilepas dan diganti dengan rubber band untuk kestabilan oklusi dan kenyamanan pasien. ${ }^{2}$

\section{Aspek penyebab disgnati dan disfagia}

Pada pemeriksaan fisik penderita ini ditemukan korelasi yang jelas antara keluhan disfagia dengan pemeriksaan fungsi oromotor yaitu drolling (+), posisi bibir yang selalu terbuka, keterbatasan gerakan maupun kontrol lidah ke depan, ke belakang, ke samping maupun ke atas. Hal ini menjelaskan mengapa penderita susah mengunyah makanan yang keras dan adanya gerakan otot yang involunter pada wajah yaitu karena adanya penurunan fungsi kontrol motorik pada korteks serebri sehingga menimbulkan gerakan yang tidak bertujuan pada wajah dapat dihubungkan dengan riwayat trauma kepala.

Pemeriksaan fisis pada fase faringeal sulit ditegagkan sehingga dibutuhkan pemeriksaan tambahan dengan flexible endoscopy evaluation swallowing (FEES) untuk melihat adanya resiko penetrasi dan aspirasi pada saat makan.

Penyebab disgnati pada penderita ini karena adanya gangguan dan perkembangan rahang bawah akibat adanya trauma kepala pada usia 5 tahun. Hal ini ditandai dengan adanya disfagia. 
Menurut Tan, insidensi disfagia pasca trauma kepala dapat mencapai $27 \%$. Penanganan umum disfagia pada penderita ini adalah mencegah komplikasi akibat aspirasi dan penanganan psikologis akibat drolling. ${ }^{6}$

Komplikasi yang mungkin terjadi pada teknik ini adalah perdarahan, parastesi oleh karena trauma pada bundel neurovaskular alveolaris inferior, pembengkakan, infeksi, fraktur pada tulang (unanticipated bony split), relaps, gangguan jalan nafas, non-union (inadequat closure).

\section{SIMPULAN}

Bedah ortognati merupakan suatu tindakan untuk mengkoreksi proporsi wajah yang tidak normal dengan mengkombinasikan perawatan ortodonti dan bedah rahang. Dilaporkan suatu kasus disgnati kelas II skeletal dirawat dengan bedah ortognatik meliputi bilateral sagittal split osteotomy, chinplasty dan V-Y plastic upper lip menunjukkan hasil yang memuaskan walaupun dengan faktor penyulit penurunan fungsi kontrol motorik dapat mempengaruhi keberhasilan dalam mengoreksi kasus disgnati klas II skeletal.

\section{SARAN}

Pada kelainan skeletal proporsi wajah perlu dilakukan perawatan bedah ortognati untuk mendapatkan hasil yang lebih baik.

\section{DAFTAR PUSTAKA}

1. Blakey GH, White RP. Mandibular surgery. In: Contemporary treatment of dentofacial deformity. St Louis: Mosby; 2003.

2. Tuinzing DB, Greebe RB, Dorenbos J, Becking AG. Surgical orthodontics: Classification, diagnosis and treatment classification, diagnosis and treatment. Maarssen: Elsevier; 2005. p.50-68, 79-86.

3. Ghali GE, Sikes JW. Intraoral vertical ramus osteotomy as the preferred treatment for mandibular prognathism. J Oral Maxillofac Surg 2000; 58: 313-5.

4. Wolford LM. The sagittal split ramus osteotomy as the preferred treatment for mandibular prognathism. J Oral Maxillofac Surg 2000; 58: 310-2.

5. Westermark A. Inferior alveolar nerve function after mandibular osteotomies. $\mathrm{Br} \mathrm{J}$ Oral Maxillofac Surg 1998; 36 (6): 425-8.

6. Tan JC. Practical manual of physical medicine and rehabilitation. St. Louis: Mosby Inc.; 1998. p. 514-37. 